\title{
Changes in glucose transporter expression in monocytes of periparturient dairy cows
}

\author{
N. J. O'Boyle, G. A. Contreras, S. A. Mattmiller, and L. M. Sordillo' \\ College of Veterinary Medicine, Michigan State University, East Lansing 48824
}

ABSTRACT

The transition period of dairy cows is characterized by dramatic changes in metabolism and immune cell function that contributes to increased susceptibility to several economically important diseases. Monocyte and macrophage populations increase in blood and tissues of cows during the transition period and have enhanced inflammatory responses that may contribute to increased severity of disease. Glucose is a major energy source for activated monocytes and glucose uptake is facilitated by glucose transporters (GLUT). The objective of this study was to determine how bovine monocyte GLUT expression changes during lactogenesis and in response to proinflammatory stimulation. Blood samples were collected from 10 dairy cows approximately 5 wk before calving and during the first week of lactation. Monocytes were isolated from total peripheral blood mononuclear cells, and expression of GLUT1, GLUT3, and GLUT4 isoforms was assessed in resting cells and following endotoxin stimulation. In general, the onset of lactation served to decrease overall GLUT expression. Gene and protein expression of GLUT1 was significantly decreased after parturition, and GLUT3 and GLUT4 cell surface expression was also significantly decreased postcalving. Endotoxin stimulation, however, increased gene expression of GLUT3 and GLUT4, and gene expression for all GLUT isoforms was positively correlated to production of tumor necrosis factor- $\alpha$. This study identified, for the first time, the presence of GLUT isoforms in bovine monocytes. Alterations in monocyte GLUT expression at the onset of lactation warrant further investigation to ascertain how changes in glucose uptake may contribute to periparturient inflammatory dysfunction.

Key words: glucose transporter, monocyte, periparturient period, inflammation

Received January 6, 2012

Accepted May 29, 2012.

${ }^{1}$ Corresponding author: Sordillo@msu.edu

\section{INTRODUCTION}

Almost half of all dairy cows in North America succumb to periparturient disorders (Goff, 2006), representing a huge financial loss to the dairy industry and causing animal welfare concerns. Increased incidence of disease during the periparturient period is directly related to dysfunctional host defense mechanisms (Sordillo and Streicher, 2002; Aitken et al., 2011). Shifts in peripheral blood mononuclear cell (PBMC) composition during the periparturient period result in significant increases in the proportion of blood monocytes and tissue macrophages (Park et al., 1992; Sordillo et al., 1995). Cells of the monocyte/macrophage lineage are key mediators of the innate immunity, but several studies showed compromised inflammatory responses by these cells in periparturient dairy cattle (Sordillo et al., 1995; Politis et al., 1996; Kimura et al., 1999; Preisler et al., 2000). Phagocytosis, production of reactive oxygen species, and secretion of proinflammatory cytokines are important functions of monocytes and macrophages that require high-energy utilization during an inflammatory response (Calder, 1995). Although dairy cattle have a 2 - to 3 -fold increase in energy requirements around parturition to support the onset of lactation (Drackley et al., 2001), little is known about how immune cells may compete for their energy utilization needs during the periparturient period.

Glucose is the primary energy source for most mammalian cells, including immune cells (Calder et al., 2007). The periparturient period demands dramatic changes in glucose utilization and distribution. The mammary gland requires large amounts of glucose for the onset of copious milk synthesis and secretion because glucose is the precursor of lactose (Bickerstaffe et al., 1974). Glucose uptake is controlled, in part, by the cell-surface expression of a family of glucose transporters (GLUT). These cell membrane proteins have several isoforms and each is unique in their expression, cellular dynamics, and behavior in different physiological circumstances (Carruthers et al., 2009). This diversity ensures a complex but efficient mechanism to maintain glucose homeostasis or exert precedence to specific tissues for glucose uptake. The ubiquitous GLUT1 is the 
predominant glucose transporter in the bovine mammary gland. The expression of GLUT1 is increased during lactogenesis and diminished in the nonlactation period in bovine mammary epithelial cells (Zhao and Keating, 2007). In humans, GLUT3 is thought to be restricted to tissues with a high dependency on glucose as a fuel source because it is a high-affinity transporter (Haber et al., 1993). The insulin-responsive GLUT4 is widely expressed in adipose tissue and muscle in several species (Bonnet et al., 2004; Roher et al., 2008). Relatively few studies have examined the expression of these GLUT isoforms in immune cell populations. Activation of human monocytes and lymphocytes increased expression of GLUT1 and GLUT3 on plasma membranes to facilitate glucose transport (Maratou et al., 2007; Mavros et al., 2009). Endotoxin stimulation of RAW 264.7 cells, a murine macrophage cell line, enhanced GLUT3 expression and glucose uptake (Reddy et al., 2010). By increasing surface expression of GLUT3, human macrophages obtained the cellular energy needed to enhance immune functions (Fu et al., 2004). Collectively, these previous studies emphasize that glucose transport by GLUT isomers is the rate-limiting step for glucose utilization in both resting and activated monocytes and macrophages. To date, however, the presence of GLUT isomers on bovine leukocytes is not described.

Imbalances in energy sources, such as glucose, can change the magnitude and duration of inflammatory and immune responses because of altered GLUT expression (Calder et al., 2007). Bovine blood monocytes are known to have compromised inflammatory responses around the time of calving, but the potential effect of diminished glucose uptake on monocyte function is not known. The hypothesis of this study was that bovine monocytes differentially express GLUT isoforms during times of high metabolic demand and following proinflammatory stimulation. Therefore, the objective of this study was to determine how monocyte GLUT expression changes during lactogenesis and in response to endotoxin stimulation. A greater understanding of the metabolic capabilities of the bovine monocyte in different physiological environments may provide some insight of how host immune responses are related to the incidence and severity of periparturient disease.

\section{MATERIALS AND METHODS}

\section{Animals and Diets}

All animal procedures were approved by the Michigan State University Animal Care and Use Committee. Ten healthy, mature, multiparous Holstein cows were selected at the time of dry-off from a large commercial dairy herd in Michigan. Animals were chosen based on the following criteria: $>210 \mathrm{~d}$ of gestation, SCC $<250,000$ cells $/ \mathrm{mL}$, and a BCS of 3.5 to 3.75 . Cows were monitored for health status during the trial and exhibited no lameness or other symptoms of disease. Animals were housed in freestalls and fed 2 different rations based on lactation status, including transition and lactation diets. The composition of each diet is shown in Table 1. Samples were collected 28 to $35 \mathrm{~d}$ before expected calving and at $5 \pm 2 \mathrm{~d}$ after calving.

\section{Monocyte Isolation and Flow Cytometry}

Samples were collected in the morning between 0500 and $0600 \mathrm{~h}$, after feed was delivered. Blood $(450 \mathrm{~mL})$ was obtained by jugular venipuncture and immediately mixed with $45 \mathrm{~mL}$ of a $40 \mathrm{~m} M$ EDTA solution containing ascorbic acid $(5 \mathrm{~g} / \mathrm{L})$. The PBMC were isolated by differential gradient using Ficoll-Paque Plus (GE Healthcare, Uppsala, Sweden), collected at the interface after centrifugation $(456 \times g$ for $30 \mathrm{~min})$, and washed 3 times with Hanks' balanced salt solution. A sub-sample of PBMC was collected to determine cellular populations using flow cytometry as described by Shafer-Weaver et al. (1999). Cells were incubated with each of the following mouse monoclonal antibodies that were raised against lineage-specific bovine leukocyte antigens (VMRD, Pullman, WA): CD2 (T lymphocytes, BAQ95A at 1:100 vol/vol), CD3 (T-cell receptor, MM1A at 1:100 vol/vol), CD4 (T-helper, CACT83B at 1:160 vol/vol), B-B2 (B lymphocytes, BAQ44A at 1:150 vol/vol), MG (monocyte/granulocyte, CD172a DH59B at 1:100 vol/vol), and CD14 (monocyte, M-M8 at $1: 50 \mathrm{vol} / \mathrm{vol}$ ).

The isolated PBMC were cultured for $2 \mathrm{~h}$ at $37^{\circ} \mathrm{C}$ in RPMI medium (Hyclone Laboratory, Logan, UT) supplemented with $10 \%$ fetal bovine serum (FBS). After incubation, culture dishes were washed 3 times with RPMI to remove nonadherent cells. Adherent cells were then incubated in RPMI $+10 \%$ FBS for $1 \mathrm{~h}$, with the addition of either F12K medium (control) or endotoxin (LPS, $100 \mathrm{ng} / \mathrm{mL}$ ). Medium was then removed and monocytes (adherent cells) were harvested by adding $10 \mathrm{~mL}$ of RPMI $+10 \%$ FBS and $10 \mathrm{~mL}$ of $10 \mathrm{mM}$ EDTA in $1 \times$ PBS. Flow cytometry was used to assess monocyte enrichment by comparing the distribution of mononuclear cells in the adherent cell population with PBMC evaluated before the nonadherent cells were removed.

Enriched populations of monocytes were incubated for 30 min with each of the following: mouse monoclonal antibody to human GLUT1 (1:1000, Abcam, Cambridge, MA), mouse monoclonal antibody to human GLUT3 (1:100, Santa Cruz Biotechnology, Santa Cruz, CA), and goat polyclonal antibody to human GLUT4 
Table 1. Ingredient composition ${ }^{1}$ of precalving (transition) and lactation diets

\begin{tabular}{|c|c|c|}
\hline \multirow[b]{2}{*}{ Item } & \multicolumn{2}{|c|}{ Diet } \\
\hline & Transition & Lactation \\
\hline \multicolumn{3}{|l|}{ Ingredient $^{1}$} \\
\hline Alfalfa haylage & 0 & 6.52 \\
\hline Corn silage & 14.27 & 23.53 \\
\hline Wheat straw & 4.24 & 0.46 \\
\hline Wet corn gluten & 1.23 & 1.14 \\
\hline Dry corn gluten & 0 & 1.28 \\
\hline Bakery byproduct & 0 & 1.23 \\
\hline Canola meal & 0 & 1.00 \\
\hline Corn bran medium grind & 0 & 1.78 \\
\hline Soybean meal, solvent & 0 & 2.01 \\
\hline Dried citrus pulp & 0 & 1.28 \\
\hline Wet beet pulp & 0 & 3.97 \\
\hline High-moisture corn & 0 & 2.22 \\
\hline Supplements and mineral mix & 0.55 & 1.60 \\
\hline Vitamin A D E mix ${ }^{2}$ & 0.04 & 0.02 \\
\hline Trace mineral $\operatorname{mix}^{3}$ & 0 & 0.02 \\
\hline Selenium blend ${ }^{4}$ & 0.05 & 0 \\
\hline Vitamin $\mathrm{E}^{5}$ & 0.005 & 0 \\
\hline Sodium selenate & 0.003 & 0 \\
\hline Sodium sesquicarbonate & 0 & 0.52 \\
\hline Calcium carbonate & 0.1314 & 0.47 \\
\hline Sodium chloride & 0.078 & 0.26 \\
\hline Ground soybean hulls & 0.096 & 0 \\
\hline Wheat middlings & 0 & 1.2 \\
\hline Magnesium sulfate & 0.187 & 0 \\
\hline Calcium sulfate & 0.311 & 0 \\
\hline Magnesium oxide & 0.062 & 0.067 \\
\hline Blood meal & 0.187 & 0.552 \\
\hline Fishmeal & 0.062 & 0.247 \\
\hline Biotin $1 \%$ & 0.005 & 0.004 \\
\hline Mepron $^{6}$ & 0 & 0.01 \\
\hline Tallow & 0.024 & 0.1 \\
\hline Rumensin $80^{7}$ & 0.004 & 0.003 \\
\hline Total & 21.535 & 50.213 \\
\hline \multicolumn{3}{|l|}{ Chemical analysis, \% of DM } \\
\hline NDF & 50.9 & 29.2 \\
\hline $\mathrm{ADF}$ & 29.9 & 16.89 \\
\hline Ether extract & 3.08 & 3.9 \\
\hline $\mathrm{NE}_{\mathrm{L}}, \mathrm{MJ} / \mathrm{kg}$ of $\mathrm{DM}$ & 5.49 & 7.27 \\
\hline
\end{tabular}

${ }^{1}$ Values expressed in kilograms of DMI per day per cow.

${ }^{2}$ Vitamin ADE mixture contained $(\mathrm{g} / \mathrm{kg}) 10.8$ retinyl acetate, 0.18 cholecalciferol, and 0.047 DL- $\alpha$-tocopherol.

${ }^{3}$ Trace mineral mix contained $(\mathrm{g} / 100 \mathrm{~g}) 13.0$ calcium, 0.3 magnesium, 2.0 copper, 8.8 magnesium, 12.0 sulfur, 10.5 zinc, 0.3 manganese, 0.25 cobalt, and 0.19 iodine.

${ }^{4}$ Selenium blend contains $0.006 \%$ sodium selenite.

${ }^{5}$ Vitamin E contained $68.0 \mathrm{~g} / \mathrm{kg}$ of DL- $\alpha$-tocopherol.

${ }^{6}$ Rumen-protected methionine (Evonik Industries AG, Essen, Germany).

${ }^{7}$ Elanco Animal Health (Greenfield, IN).

(1:200, Santa Cruz Biotechnology). After 3 washes with FACS (fluorescence-activated cell sorting) solution (comprising sterile PBS, FBS, and 10\% sodium azide solution), mononuclear cells were incubated with the corresponding secondary antibody that included either goat anti-mouse $(1: 5,000$, Pierce) for the mouse monoclonal antibodies to human GLUT1 and GLUT3 or rabbit anti-goat (1:5,000, Pierce) for the goat polyclonal antibody to human GLUT4. Flow cytometry analysis was performed using the FACSdiva software (BD Biosciences, San Jose, CA).

\section{Quantitative Real-Time PCR}

Monocyte RNA was extracted for quantification of GLUT1, GLUT3, GLUT4, and $\beta$-actin mRNA transcript expression by quantitative, real-time PCR (qPCR) as previously described (Steibel et al., 2009; Corl et al., 2010). In brief, total RNA was extracted utilizing the Qiagen RNeasy Plus Mini Kit (Qiagen, Valencia, CA). This kit includes a step to remove genomic DNA. The purity of RNA was determined using a NanoDrop 100 spectrophotometer (Thermo Scientific, Wilmington, DE). All samples were found to have a 260 $\mathrm{nm}: 280 \mathrm{~nm}$ reading between 1.95 and 2.1. A random group of samples was analyzed on an Agilent Bioanalyzer (Agilent Technologies, Santa Clara, CA) to assess RNA integrity. All tested samples had a RNA integrity number $>6$. Purified RNA was converted to cDNA using the Applied Biosystems High Capacity cDNA Archive Kit (Applied Biosystems, Foster City, CA). All qPCR assays were conducted utilizing Custom TaqMan gene expression assays from Applied Biosystems. TaqMan primer and probe sets (Table 2) were designed from bovine sequences with the Applied Biosystems Pipeline software and synthesized by Applied Biosystems. Efficiency tests were run on each custom TaqMan gene expression assay using cDNA prepared in the same manner as all samples for analyses. Each assay was found to be $100 \%$ efficient. In-house testing also showed $\beta$-actin to be very stable for monocyte cDNA; therefore, it was chosen as the reference gene. Samples were assayed in triplicate with $100 \mathrm{ng}$ of cDNA per reaction along with $10 \mu \mathrm{L}$ of TaqMan Fast Universal PCR Master Mix $(2 \times)$, and $1 \mu \mathrm{L}$ of the appropriate TaqMan Gene Expression Assay Mix $(20 \times)$ on the Applied Biosystems 7500 Fast Real-Time PCR System. The relative quantification of each gene was calculated utilizing the 7500 Fast SDS Software (version 1.3.1, Applied Biosystems). Data were calculated based on the comparative cycle threshold $(\mathrm{Ct})$ method $\left(2^{-\Delta \Delta \mathrm{Ct}}\right)$ of relative quantification using $\beta$-actin as the reference gene (Livak and Schmittgen, 2001; Steibel et al., 2009). The calibrator was set as the precalving unstimulated sample.

\section{Western Blot Analyses}

Protein quantification was performed by protein blot analysis as previously described (Corl et al., 2010). 
Table 2. Gene targets and primer and probe sequences for quantitative real-time PCR

\begin{tabular}{|c|c|c|c|}
\hline Target $^{1}$ & $\begin{array}{l}\text { GenBank } \\
\text { accession no. }\end{array}$ & Primer & Sequence $\left(5^{\prime}\right.$ to $\left.3^{\prime}\right)$ \\
\hline \multirow[t]{3}{*}{ GLUT1 } & \multirow[t]{3}{*}{ NM_174602 } & Forward & CGGCTGCCCTGGATGTC \\
\hline & & Reverse & GCCTGGGCCCACTTCAAA \\
\hline & & Probe & ATGGCCACAATGCTCA \\
\hline \multirow[t]{3}{*}{ GLUT3 } & \multirow[t]{3}{*}{ XM_001256170.1 } & Forward & CAAGTCACAGTGCTAGAGTCTTTC \\
\hline & & Reverse & GGAGAGCTGGAGCATGATAGAGAT \\
\hline & & Probe & CCGGCAACCCATCATT \\
\hline \multirow[t]{3}{*}{ GLUT4 } & \multirow[t]{3}{*}{ BC114082.1 } & Forward & GTCAACACAGTCTTCACCTTAGTCT \\
\hline & & Reverse & CCAGGCCCAGGAGATGGA \\
\hline & & Probe & CCCAGCCCGTTCCAC \\
\hline \multirow[t]{3}{*}{ TNF- $\alpha$} & \multirow[t]{3}{*}{ NM_173966 } & Forward & GCCCCCAGAGGGAAGAG \\
\hline & & Reverse & CCAGAGGGCTGTTGATGGA \\
\hline & & Probe & CCCCAGGTGGCCCC \\
\hline \multirow[t]{3}{*}{ IL1- $\beta$} & \multirow[t]{3}{*}{ NM_174093 } & Forward & GCTCTCCACCTCCTCTCACA \\
\hline & & Reverse & CTCTCCTTGCACAAAGCTCATG \\
\hline & & Probe & CAGAACACCACTTCTCG \\
\hline \multirow[t]{3}{*}{$\beta$-Actin } & \multirow[t]{3}{*}{ NM-173979 } & Forward & CCGCCCCGCTAGCA \\
\hline & & Reverse & AACTGGTTGCGGTGTCGA \\
\hline & & Probe & CCTTCGCCGCTCCGC \\
\hline
\end{tabular}

${ }^{1}$ GLUT1, GLUT3, and GLUT4 = isoforms of glucose transporter family; TNF- $\alpha=$ tumor necrosis factor- $\alpha$.

After monocyte collection, whole cell lysates were harvested in M-Per reagent (Pierce, Rockford, IL) and centrifuged at $10,000 \times g$ for $10 \mathrm{~min}$ at $4^{\circ} \mathrm{C}$ to remove membrane fractions. Supernatants were collected and total protein was quantified using the Coomassie Brilliant Blue method. Equal amounts of protein $(30 \mu \mathrm{g})$ were electrophoresed on a $10 \%$ SDS-PAGE gel and transferred to a polyvinylidene difluoride membrane. The Millipore SNAP I.D. Protein Detection System (Millipore, Billerica, MA) was utilized to carry out the remaining steps. The membrane was blocked in $0.5 \%$ dry milk in Tris-buffered saline (TBS) with $0.01 \%$ Tween-20 and washed 3 times with TBS. Membranes were incubated for 10 min with primary antibodies against human GLUT as described above for the flow cytometry: GLUT1 (1:400 dilution), GLUT3 (1:200 dilution), and GLUT4 (1:250) in 1\% BSA in TBS with $0.01 \%$ Tween-20. Following 3 washes with TBS, membranes were incubated with the correspondent anti-host IgG secondary antibody labeled with horseradish peroxidase (1:3,000 dilution in $0.5 \%$ dry milk, Pierce) for 10 min at room temperature, washed 3 times with TBS, exposed to horseradish peroxidase substrate (Pierce), and visualized by chemiluminescence using the ChemiDoc XRS (Bio-Rad, Hercules, CA) and Quantity One software (Bio-Rad). Mouse anti-human actin (1:3,000 dilution, Millipore) served as the loading control with the corresponding goat anti-mouse secondary antibody (1:3,000 dilution). Density of the bands was quantified by the Quantity One software (Bio-Rad). The ratio of specific antibodies to $\beta$-actin was calculated, and the values were expressed as a fold change over the precalving unstimulated monocytes sample.

\section{Statistical Analysis}

Variables were analyzed as repeated measures using a mixed model procedure (PROC MIXED; SAS Inst. Inc., Cary, NC). The following model was used to estimate the sampling day effect on each of the measured variables:

$$
\mathrm{Y}_{\mathrm{ij}}=\mu+\mathrm{S}_{\mathrm{i}}+\mathrm{e}_{\mathrm{ij}}
$$

where $\mathrm{Y}_{\mathrm{ij}}$ was the dependent variable for cow $\mathrm{i}$ in sample $\mathrm{j}$ relative to calving; $\mu$ is the overall mean of the population; $S_{i}$ is the fixed effect of time as the repeated factor; and $\mathrm{e}_{\mathrm{ij}}$ is the random error, assumed to be correlated. Least squares means were calculated and adjusted using the Tukey-Kramer method.

\section{RESULTS}

\section{Evaluation of PBMC Populations}

Changes in circulating leukocyte subpopulations were observed when comparing phenotype distributions during the precalving period with those obtained immediately postcalving (Figure 1). Monocyte populations were characterized in the present study by the expression of the specific monocyte-granulocyte CD172a marker and the co-receptor CD14 that is involved in endotoxin-induced monocyte activation. The proportion of monocyte populations (CD172a) increased significantly as a percentage of total PBMC just after calving $(26.41 \pm 5.2 \%)$ compared with precalving (16.2 $\pm 5 \%)$. In contrast, the T-cell subpopulation characterized by expression of the T-cell co-receptor (CD3) 


\section{$\square$ Precalving}

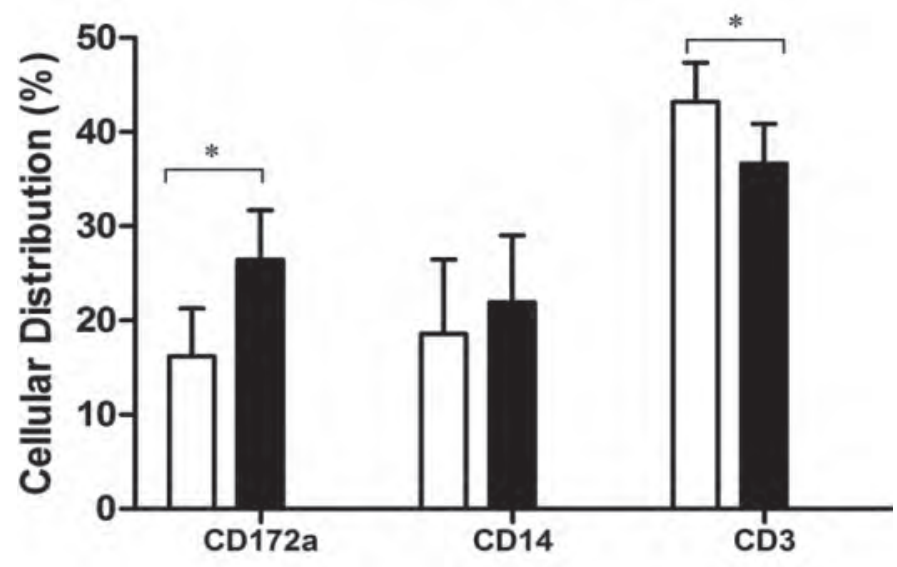

Figure 1. Changes in distribution of peripheral blood mononuclear cells (PBMC) phenotype relative to calving date in periparturient dairy cows $(\mathrm{n}=9)$. Values are percentage of the population \pm SEM as measured by flow cytometry using mouse monoclonal antibodies against lineage-specific bovine leukocyte antigens. Phenotypes were characterized by the expression of CD3 for lymphocytes and CD172a for monocytes; CD14 is a co-receptor that also identifies monocytes in the total PBMC population. Means with an asterisk differ, $P<0.05$.

significantly decreased at calving $(36.66 \pm 4.2 \%)$ compared with precalving $(43.2 \pm 4.2 \%)$. As for the monocyte co-receptor CD14, no differences were observed between precalving $(18.56 \pm 7.9 \%)$ and postcalving samples $(21.94 \pm 7.1 \%)$.

The efficiency of isolating monocytes from the total PBMC population for in vitro assay was determined by flow cytometric analyses using phenotype-specific cell markers CD172a and CD14. The lineage-specific cell markers verified the monocytes to be isolated to at least $80 \%$ of the cell population (Figure 2).

\section{Monocyte GLUT Expression}

The mRNA abundance of GLUT1 significantly decreased postcalving compared with precalving expression (Figure 3A). Protein expression was assessed using blot densitometry and statistical comparison was calculated using the glucose transporter to actin ratios. As reflected in the gene transcription findings, GLUT1 protein expression decreased significantly during postcalving compared with precalving (Figure 3B). Fluorescence intensity values were used to characterize changes in glucose transporter cell-surface protein expression. Cell-surface protein expression of GLUT1 did not significantly differ from precalving to postcalving (Figure 3C)
Gene expression of GLUT3 did not significantly change over sampling time points (Figure 4A). Protein expression of GLUT3 also remained unchanged relative to both sampling time points (Figure 4B). Significant changes in cell-surface protein expression were observed for GLUT3, which decreased significantly from precalving to postcalving (Figure $4 \mathrm{C}$ ).

No changes in GLUT4 gene expression were observed with respect to stage of lactation (Figure 5A). Protein expression of GLUT4, however, did decrease

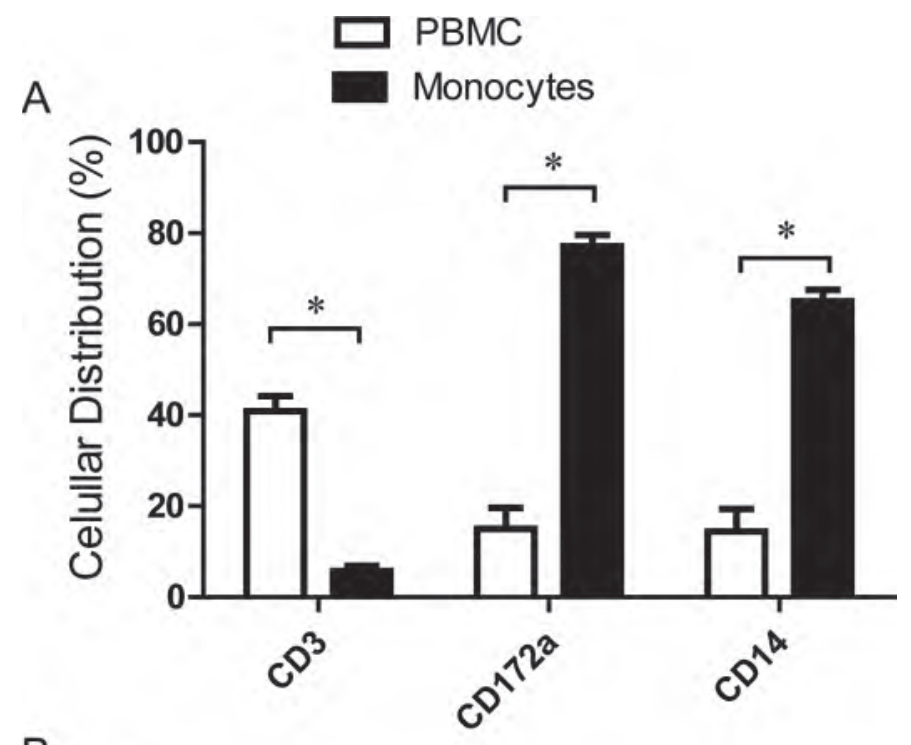

$B$

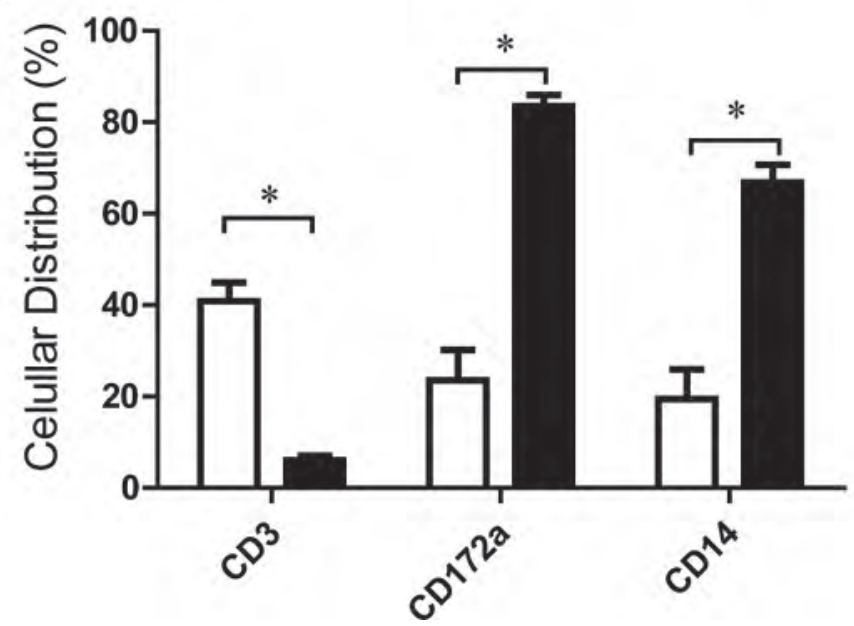

Figure 2. Efficiency of monocyte isolation from peripheral blood mononuclear cells (PBMC). Figures represent phenotype distribution in $\mathrm{PBMC}$ and isolated monocytes precalving $(\mathrm{A})$ and postcalving $(\mathrm{B})$ $(\mathrm{n}=9)$. Values are percentage of the population \pm SEM as measured by flow cytometry using mouse monoclonal antibodies against lineage-specific bovine leukocyte antigens. Phenotypes were characterized by the expression of CD3 for lymphocytes and CD172a for monocytes; CD14 is a co-receptor that also identifies monocytes in the total PBMC population. Means with an asterisk differ, $P<0.05$. 
A

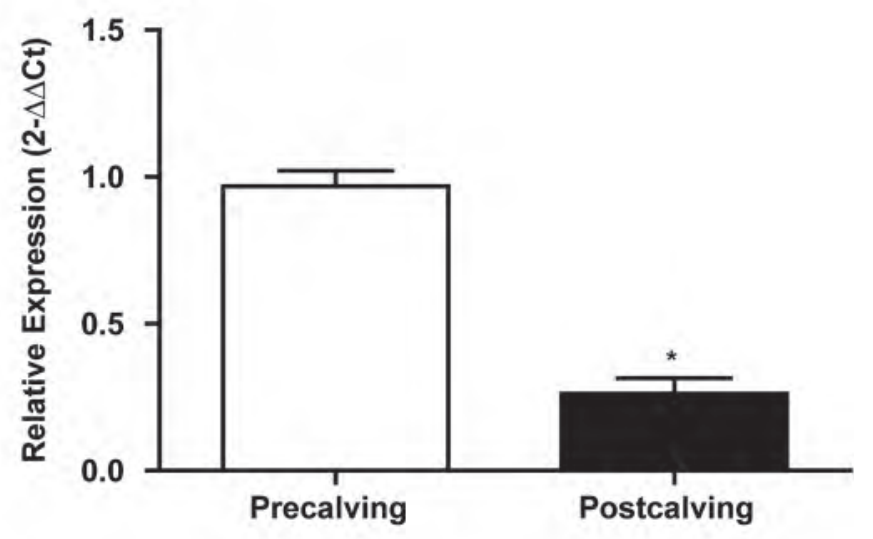

B

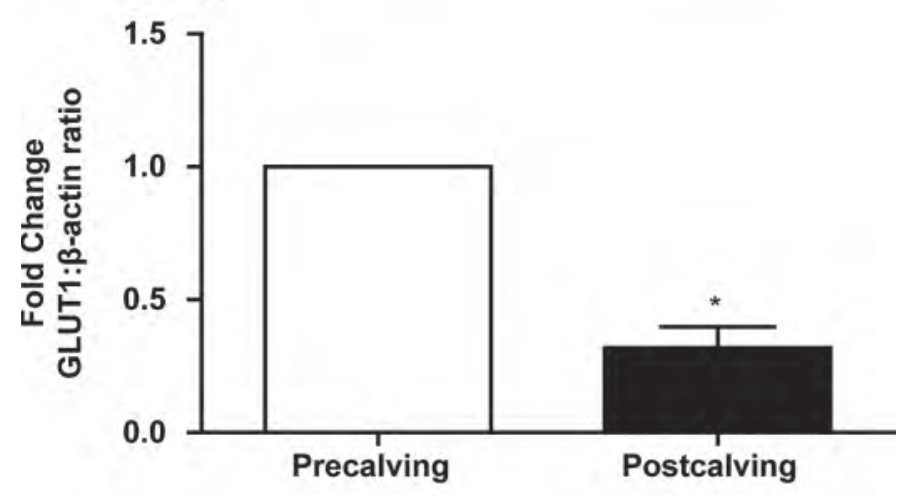

C

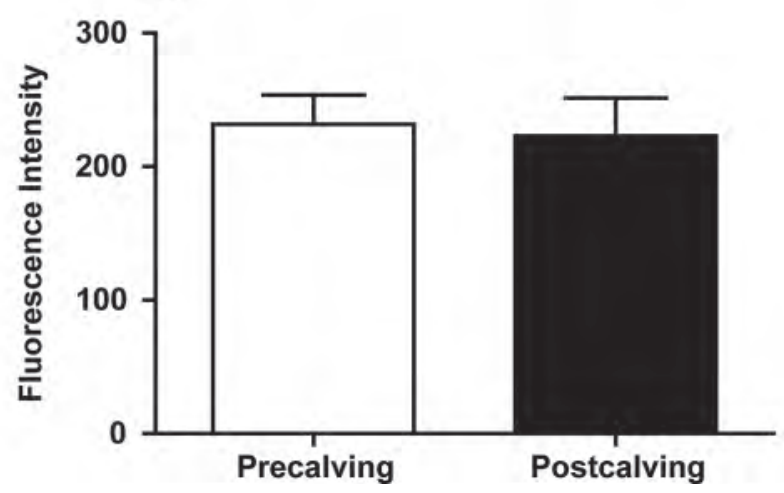

Figure 3. Analysis of glucose transporter (GLUT)1 mRNA expression $(A ; n=6)$, protein expression $(B ; n=7)$, and cell surface expression on monocytes $(\mathrm{C} ; \mathrm{n}=7)$ pre- and postcalving. (A) Data reported as least squares means \pm SEM. Significant differences $(P<0.05)$ are represented with an asterisk. Data were analyzed by the $2^{-\Delta \Delta C}$ method with precalving as the reference expression point. (B) Data reported as a ratio of GLUT: $\beta$-actin \pm SEM. Significant differences $(P$ $<0.05)$ are represented with an asterisk. Data were analyzed by the fold-change in protein expression using precalving as the calibrator (C) Values expressed as fluorescence intensity of positive monocytes \pm SEM as measured by flow cytometry. Means with an asterisk differ, $P<0.05$ significantly from precalving values compared with postcalving values (Figure 5B), and surface expression of GLUT4 decreased significantly from precalving to postcalving (Figure 5C).

\section{Endotoxin Stimulation Alters Monocyte GLUT Expression}

The effect of stimulating isolated bovine monocytes with endotoxin on GLUT expression was established (Figure 6). At the transcription level, we observed a significant increase in the expression of GLUT3 and GLUT4 when monocytes were exposed to endotoxin. In contrast, we found no changes in gene expression of GLUT1. When analyzing protein abundance of GLUT1, GLUT3, and GLUT4, no effects were observed after exposure to endotoxin.

\section{Lactation Stage and Endotoxin Stimulation Effects on GLUT Expression}

The effects of the interaction between lactation stage and endotoxin stimulation were analyzed (Table 3). No significant interaction effects between lactation stage and endotoxin stimulation were observed for GLUT1 and GLUT3 gene expression. We did observe a significant effect of calving date on GLUT1 expression and a significant effect of endotoxin stimulation of GLUT3 expression. Gene expression of GLUT4 in response to endotoxin was significantly higher before parturition than after calving, but no differences were observed after calving.

\section{GLUT and Proinflammatory Cytokine Expression}

We further analyzed the correlations between the expression of different GLUT and specific proinflammatory cytokines (Table 4). Expression of monocyte tumor necrosis factor- $\alpha$ (TNF- $\alpha$ ) was positively correlated with the expression of GLUT1, GLUT3, and GLUT4. Expression of IL-1 $\beta$ was strongly correlated with the gene expression of GLUT3.

\section{DISCUSSION}

The present study demonstrated an increased percentage of monocytes in the total PBMC population obtained from cows during the onset of lactation. These findings are consistent with previous studies that demonstrated not only increased percentages, but also altered proinflammatory functions of monocytes in PBMC populations obtained from periparturient cows (Sordillo et al., 1995; Politis et al., 1996; Preisler et al., 2000). Monocytes and macrophages require 
A

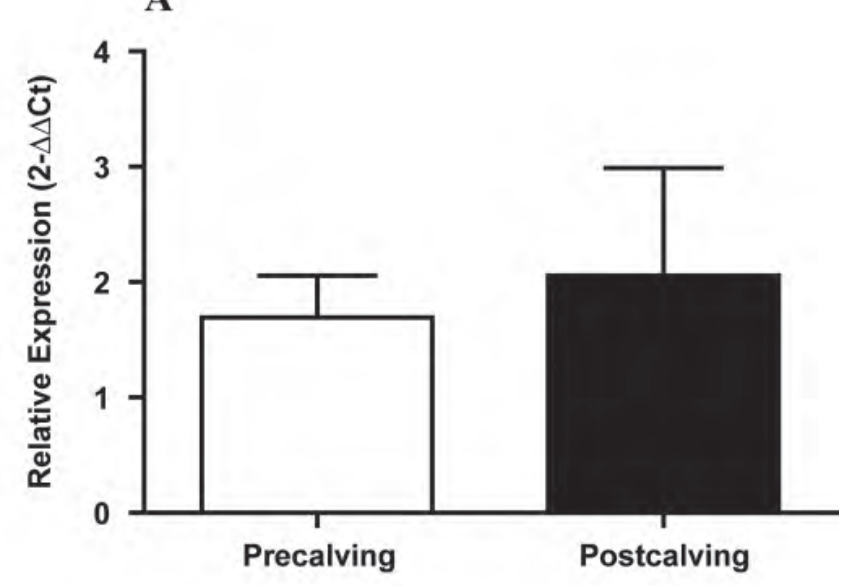

B

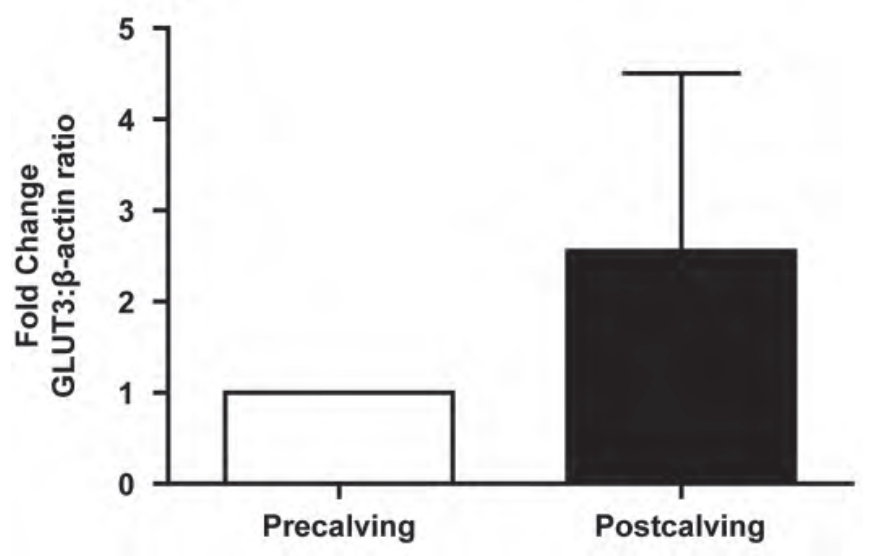

C

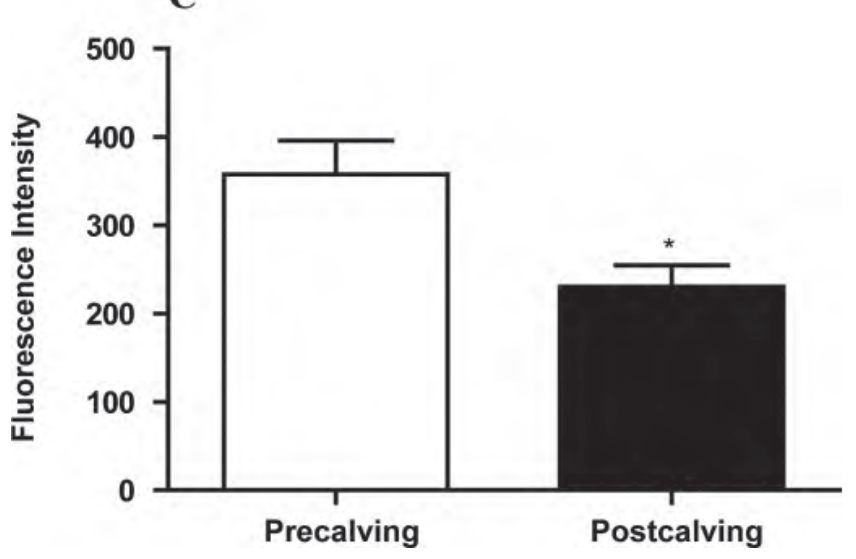

Figure 4. Analysis of glucose transporter (GLUT) 3 mRNA expression $(\mathrm{A} ; \mathrm{n}=6)$, protein expression $(\mathrm{B} ; \mathrm{n}=7)$, and cell surface expression on monocytes $(\mathrm{C} ; \mathrm{n}=7)$ pre- and postcalving. (A) Data reported as least squares means \pm SEM. Significant differences $(P$ $<0.05)$ are represented with an asterisk. Data were analyzed by the $2^{-\Delta \Delta \mathrm{Ct}}$ method with precalving as the reference expression point. (B) Data reported as a ratio of GLUT: $\beta$-actin \pm SEM. Significant differences $(P<0.05)$ are represented with an asterisk. Data were analyzed by the fold-change in protein expression using precalving as the calibrator. (C) Values are expressed as fluorescence intensity of positive monocytes \pm SEM as measured by flow cytometry. Means with an asterisk differ, $P<0.05$. considerable energy to support their proinflammatory functions, and glucose serves as a primary fuel source (Calder et al., 2007). The rate-limiting step in glucose uptake and utilization for several immune cell populations, including monocytes, is determined by the expression of GLUT (Calder et al., 2007). This study showed for the first time that GLUT1, GLUT3, and GLUT4 isoforms are expressed on bovine monocytes during the periparturient period. The findings presented here are consistent with previous studies showing that both murine and human monocyte express these GLUT isoforms and that glucose utilization rates by both resting and activated monocytes are high (Malide et al., 1998; Maratou et al., 2007; Reddy et al., 2010). The expression of several different GLUT isoforms on monocytes supports the contention that uptake of glucose is a complicated process involving the coordinated expression of these transport proteins under different physiological conditions.

The periparturient period is a time of increased metabolic demands and the majority of available glucose is partitioned to the mammary gland for milk synthesis and secretion (Bickerstaffe et al., 1974). Information is lacking, however, on how bovine immune cell populations may compete for glucose during the physiological transition from late gestation to the onset of lactation by altering the expression of GLUT. The results from this study suggest that the expression of GLUT1, GLUT3, and GLUT4 was reduced to some extent during early lactation compared with the precalving period. Interestingly, the level of regulation with respect to transcript or protein expression was unique depending on the specific isoform. For example, GLUT1 expression was significantly reduced at the mRNA and total protein levels, but surface expression remained unchanged with respect to lactation stage. These findings contrast with observations in the bovine mammary gland, where GLUT1 expression increases substantially as lactation ensues, and GLUT1 is recognized as the predominant glucose transporter (Zhao and Keating, 2007; Mattmiller et al., 2011). Generally, GLUT1 serves to produce glycemic equilibrium; expression typically decreases in hyperglycemia and increases in hypoglycemia (Duelli et al., 1998, 2000; Smoak and Branch, 2000). Although conjecture, the contrast in GLUT1 expression between circulating monocytes and mammary gland tissues could be explained by the localized physiological environment of the mammary gland, which may serve to increase GLUT1 expression; for example, hypoxia (Bashan et al., 1992; RodríguezEnríquez et al., 2010) and hyperosmolarity (Hwang and Ismail-Beigi, 2001). The upregulation of GLUT1 by lactogenic hormones that favor milk synthesis was also proposed (Zhao and Keating, 2007). In contrast 
$\mathbf{A}$

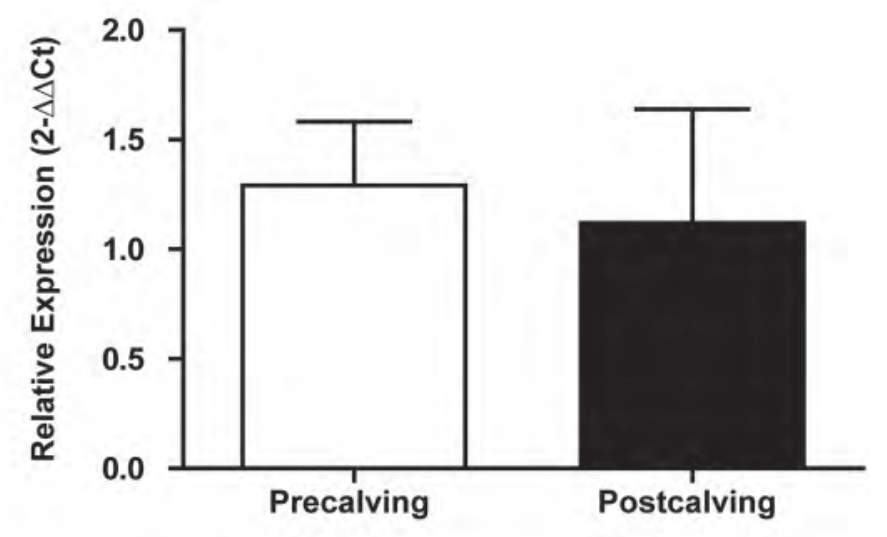

B
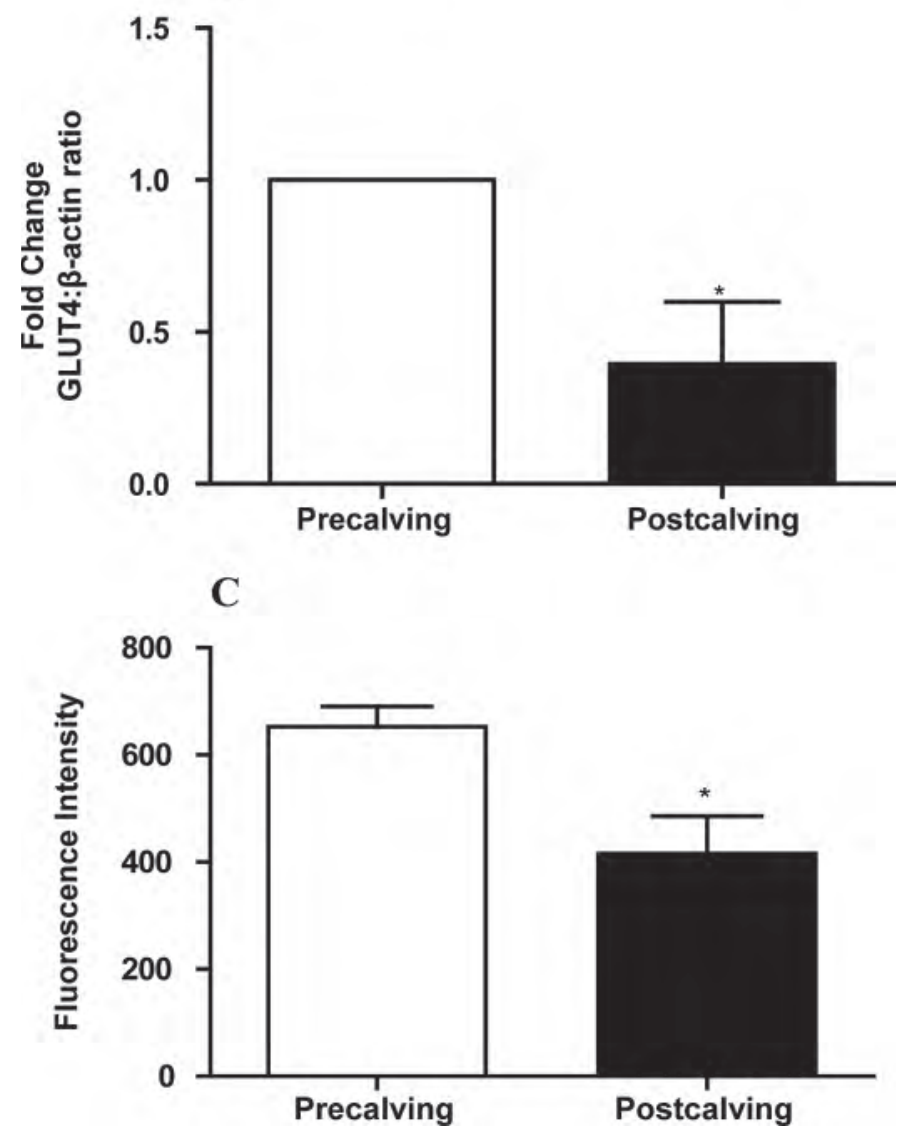

Figure 5. Analysis of glucose transporter (GLUT) 4 mRNA expression $(A ; n=6)$, protein expression $(B ; n=7)$, and cell surface expression on monocytes $(\mathrm{C} ; \mathrm{n}=7)$ pre- and postcalving. (A) Data reported as least squares means \pm SEM. Significant differences $(P$ $<0.05)$ are represented with an asterisk. Data were analyzed by the $2^{-\Delta \Delta \mathrm{Ct}}$ method with precalving as the reference expression point. (B) Data reported as a ratio of GLUT: $\beta$-actin \pm SEM. Significant differences $(P<0.05)$ are represented with an asterisk. Data were analyzed by the fold-change in protein expression using the precalving value as the calibrator. (C) Values are expressed as fluorescence intensity of positive monocytes \pm SEM as measured by flow cytometry. Means with an asterisk differ, $P<0.05$.

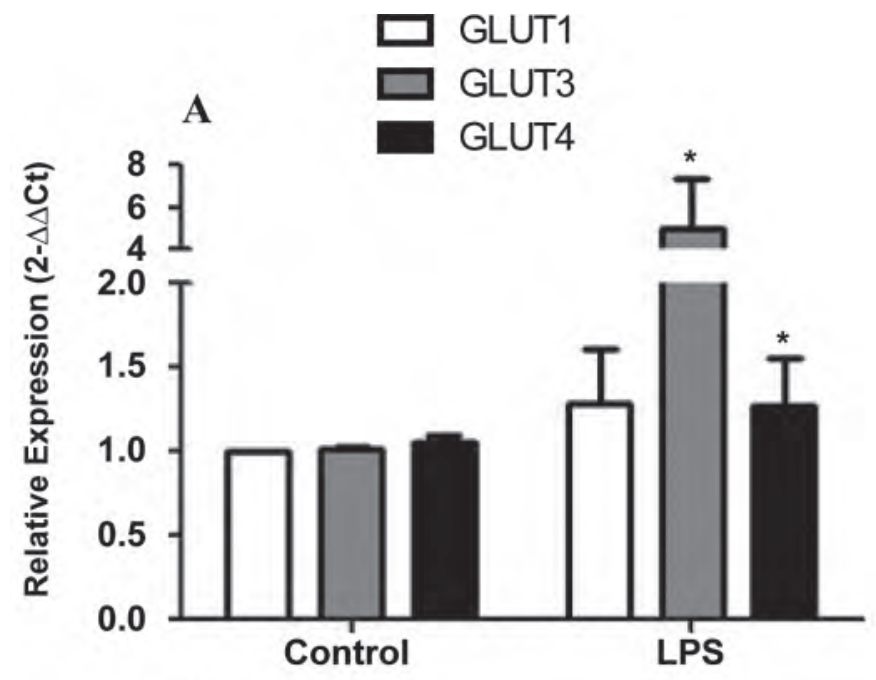

B

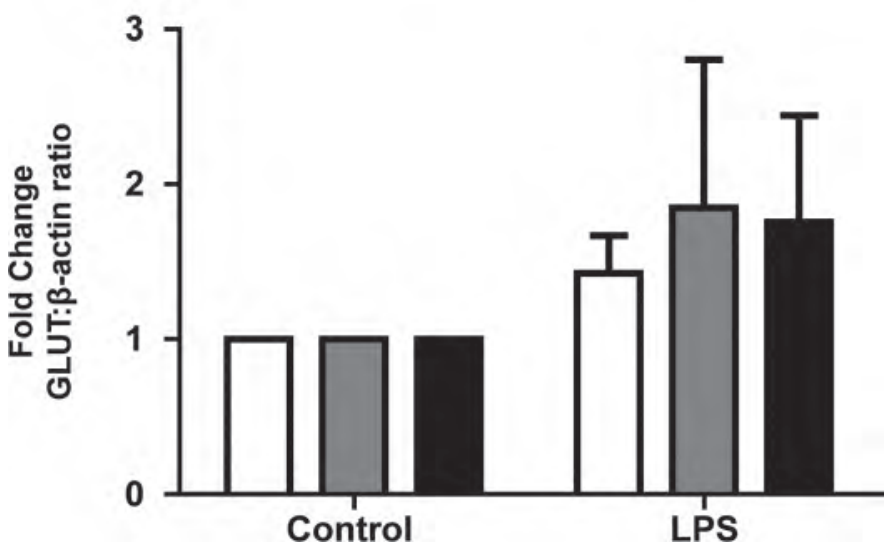

Figure 6. Effect of stimulation with LPS on mRNA expression (A; $\mathrm{n}=6)$ and protein expression ( $\mathrm{B} ; \mathrm{n}=7$ ) of glucose transporters. (A) Data reported as least squares means \pm SEM. Significant differences $(P<0.05)$ are represented with an asterisk. Data were analyzed by the $2^{-\Delta \Delta \mathrm{Ct}}$ method with control as the reference expression point. (B) Data reported as a ratio of GLUT: $\beta$-actin \pm SEM. Significant differences $(P$ $<0.05)$ are represented with an asterisk. Data were analyzed by the fold-change in protein expression using control as the calibrator.

to mammary tissues, circulatory monocytes are subject to a more homeostatic environment, with more flexibility in metabolic fuels such as glutamine, glutamate, and fatty acids (Calder, 1995; Newsholme, 2001). The periparturient dairy cow maintains a high level of glutamine postpartum, likely due to muscle catabolism, although this does decrease as lactation progresses (Zhu et al., 2000). Our descriptive study did not look at actual glucose uptake, although we could speculate that glucose uptake is decreased in monocytes as glucose is prioritized to the mammary gland during lactogenesis. Further studies exploring monocyte GLUT1 expression and actual glucose uptake in different physiological conditions such as hypoxia are warranted. Future studies 
Table 3. Least squares means for log-transformed glucose transporter (GLUT) mRNA expression values $(\Delta$ cycle threshold) comparing the effects of calving date (Date), endotoxin stimulation (treatment, Trt), and the interaction between them $(\mathrm{n}=6)$

\begin{tabular}{|c|c|c|c|c|c|c|}
\hline \multirow[b]{2}{*}{ Gene } & \multicolumn{2}{|c|}{ Treatment } & \multirow[b]{2}{*}{ SEM } & \multicolumn{3}{|c|}{$P$-value } \\
\hline & Control & LPS & & Date & Trt & Date $\times$ Trt \\
\hline GLUT1 & 0.750 & 0.720 & 0.166 & 0.04 & 0.86 & 0.41 \\
\hline GLUT3 & 1.093 & 0.382 & 0.174 & 0.09 & $<0.01$ & 0.70 \\
\hline GLUT4 $^{1}$ & 0.367 & -0.587 & 0.361 & 0.19 & 0.05 & 0.04 \\
\hline
\end{tabular}

${ }^{1}$ An interaction between calving date and LPS treatment increased GLUT4 mRNA expression precalving, following LPS treatment $(P=0.035)$.

that examine how monocytes utilize alternate sources of available energy, such as glutamine, also may lead to a better understanding of why inflammatory responses are compromised during lactogenesis.

Glucose transporter 3 is a high-affinity isoform typically located in tissues that require rapid bursts of metabolic energy, such as the developing blastocyst (Pantaleon et al., 1997), neural tissue, sperm cells (Haber et al., 1993), and white blood cells (Maratou et al., 2007). A previous study indicated that GLUT3 mRNA was only present at very low levels in certain bovine tissues (Zhao et al., 1993). In the present study, GLUT3 expression was not only found on bovine monocytes, but was also observed to be less abundant after calving, with significant decreases in cell-surface protein expression. Insulin and IGF-1 are known to positively affect expression and uptake of glucose via GLUT3 in human monocytes (Estrada et al., 1994). Although speculative at this time, the postpartum decrease in both insulin and IGF-1 in the dairy cow (Lucy et al., 2001; Llewellyn et al., 2007) may contribute to the reduced expression of GLUT3. Further observations of GLUT3 expression and function on bovine monocytes with differing concentrations of insulin and IGF-1 are warranted.

Glucose transporter 4 is the most insulin-responsive isoform of the GLUT family. The proposed mechanism involves the translocation of GLUT4 to the membrane as a result of insulin exposure rather than glucose con-

Table 4. Pearson correlation coefficients (r) and $P$-values for glucose transporter (GLUT1, GLUT3, and GLUT4) and cytokine gene expression (tumor necrosis factor- $\alpha$ and IL-1 $\beta$ ) from transition dairy cows $(\mathrm{n}=6)$

\begin{tabular}{llcc}
\hline & & \multicolumn{2}{c}{ Cytokine } \\
\cline { 3 - 4 } Gene & Value & TNF- $\alpha$ & IL-1 \\
\hline GLUT1 & $\mathrm{r}$ & 0.51 & 0.22 \\
& $P$ & 0.01 & $\mathrm{NS}$ \\
GLUT3 & $\mathrm{r}$ & 0.76 & 0.74 \\
& $P$ & $<0.0001$ & $<0.0001$ \\
GLUT4 & $\mathrm{r}$ & 0.42 & 0.10 \\
& $P$ & 0.04 & $\mathrm{NS}$ \\
\hline
\end{tabular}

${ }^{1} \mathrm{NS}: P>0.05$. centration (Hansen et al., 1998). In fact, the increase in GLUT4 surface expression on adipocytes was shown to be dependent on insulin dose (Govers et al., 2004). The current study showed that both protein and cellsurface expression of GLUT4 decreased significantly postcalving. Previous reports did not detect GLUT4 in the bovine mammary gland in dry or lactating stages (Zhao et al., 1996). Although insulin was not measured, our descriptive findings are consistent with the theory that decreased GLUT4 translocation may occur during times of low insulin concentrations, such as lactogenesis in the dairy cow (Lomax et al., 1979). The decline in insulin during lactogenesis is thought to reflect the homeorhetic drive for milk production (Bonczek et al., 1988; Ingvartsen et al., 2003). In fact, hypoinsulinemia is the most positively correlated change among hormones or metabolites with regard to differences in milk yield (Ingvartsen and Friggens, 2005). Similar behavior was observed in human monocytes with insulin, and this interaction was reviewed as a potential indicator of metabolic health as well as a marker of insulin resistance (George et al., 2005; Mavros et al., 2009). The possibility that insulin levels could affect GLUT4 behavior within the bovine monocyte should be investigated further based on these initial descriptive studies.

Enhanced TNF- $\alpha$ expression is an important marker of inflammation and function in monocyte-macrophage lineages obtained from periparturient dairy cattle (Aitken et al., 2011). The current study showed, for the first time, that GLUT1, GLUT3, and GLUT4 expression by bovine monocytes obtained during the periparturient period was positively correlated with TNF- $\alpha$ expression. These findings are consistent with the prevailing theory that monocytes require glucose uptake for cytokine production and that GLUT expression is essential for glucose utilization (Calder et al., 2007). The stimulation of bovine monocytes with endotoxin also resulted in a significant increase in mRNA expression of both GLUT3 and GLUT4. These findings are consistent with previous studies that showed an increase in these isoforms following activation of human and murine monocytes (Fukuzumi et al., 1996; Malide et al., 1998; Fu 
et al., 2004; Maratou et al., 2007). Although previous studies reported increased GLUT expression on various stimulated immune cell populations, the data presented here are the first to show that GLUT expression on bovine monocytes also shifts in response to inflammatory agonists. Moreover, the lack of endotoxin-induced GLUT1 expression observed in this study may suggest that this isoform does not play a predominant role in monocyte function during inflammation compared with GLUT3 and GLUT4. Only GLUT4, however, showed a significant interaction between stage of lactation and endotoxin stimulation. Bovine monocytes obtained during the immediate postpartum period produce more TNF- $\alpha$ following endotoxin stimulation compared with those obtained from late-lactation cows (Sordillo et al., 1995). Although conjecture, the results from this study suggest that GLUT4 may be the isoform most crucial for supplementing the energy needs of monocytes during times of enhanced activation, such as the periparturient period.

The metabolic switch during the onset of lactogenesis is associated with compromised immune and inflammatory responses (Sordillo et al., 2009). A possible contributing factor to dysfunctional inflammatory responses may be the limited glucose uptake because of reduced GLUT expression. This study tested the hypothesis that bovine monocytes differentially express GLUT isoforms during times of high metabolic demands and following proinflammatory stimulation. Results showed for the first time that GLUT expression in bovine monocytes decreases from late gestation to early lactation when the majority of total body glucose is partitioned to the mammary gland to sustain copious milk synthesis and secretion. The reduction in surface expression of GLUT3 and GLUT4 on monocytes may limit the uptake of glucose needed for optimal function. Conversely, the significant increase in mRNA expression of monocyte GLUT following endotoxin stimulation and the positive correlation with TNF- $\alpha$ production support the contention that glucose uptake is related to monocyte proinflammatory functions. Although these experiments were descriptive in nature and did not measure glucose uptake, the findings provide novel information to further explore how limited energy utilization in monocytes may contribute to dysfunctional inflammatory responses in periparturient dairy cows.

\section{ACKNOWLEDGMENTS}

This project was funded in part by the Michigan Milk Producers Association (Novi, MI) and by an endowment from the Matilda R. Wilson Fund (Detroit, MI). The authors are also grateful to Jeff Gandy, Candice Gandy, Chris Corl, Elizabeth Karcher, Juan David Mu- noz (all from Michigan State University, East Lansing), and staff at Willow Point Dairy (Iona, MI) for their technical assistance.

\section{REFERENCES}

Aitken, S. L., C. M. Corl, and L. M. Sordillo. 2011. Immunopathology of mastitis: Insights into disease recognition and resolution. J. Mammary Gland Biol. Neoplasia 16:291-304.

Bashan, N., E. Burdett, H. S. Hundal, and A. Klip. 1992. Regulation of glucose transport and GLUT1 glucose transporter expression by $\mathrm{O}_{2}$ in muscle cells in culture. Am. J. Physiol. 262:C682-C690.

Bickerstaffe, R., E. F. Annison, and J. L. Linzell. 1974. The metabolism of glucose, acetate, lipids and amino acids in lactating dairy cows. J. Agric. Sci. 82:71-85.

Bonczek, R. R., C. W. Young, J. E. Wheaton, and K. P. Miller. 1988. Responses of somatotropin, insulin, prolactin, and thyroxine to selection for milk yield in Holsteins. J. Dairy Sci. 71:2470-2479.

Bonnet, M., Y. Faulconnier, J. F. Hocquette, F. Bocquier, C. Leroux, P. Martin, and Y. Chilliard. 2004. Nutritional status induces divergent variations of GLUT4 protein content, but not lipoprotein lipase activity, between adipose tissues and muscles in adult cattle. Br. J. Nutr. 92:617-625.

Calder, P. C. 1995. Fuel utilization by cells of the immune system. Proc. Nutr. Soc. 54:65-82.

Calder, P. C., G. Dimitriadis, and P. Newsholme. 2007. Glucose metabolism in lymphoid and inflammatory cells and tissues. Curr. Opin. Clin. Nutr. Metab. Care 10:531-540.

Carruthers, A., J. DeZutter, A. Ganguly, and S. U. Devaskar. 2009. Will the original glucose transporter isoform please stand up! Am. J. Physiol. Endocrinol. Metab. 297:E836-E848.

Corl, C. M., H. R. Robinson, G. A. Contreras, S. J. Holcombe, V. L. Cook, and L. M. Sordillo. 2010. Ethyl pyruvate diminishes the endotoxin-induced inflammatory response of bovine mammary endothelial cells. J. Dairy Sci. 93:5188-5199.

Drackley, J. K., T. R. Overton, and G. N. Douglas. 2001. Adaptations of glucose and long-chain fatty acid metabolism in liver of dairy cows during the periparturient period. J. Dairy Sci. 84(E.Suppl.):E100-E112.

Duelli, R., M. H. Maurer, and W. Kuschinsky. 1998. Decreased glucose transporter densities, rate constants and glucose utilization in visual structures of rat brain during chronic visual deprivation. Neurosci. Lett. 250:49-52.

Duelli, R., M. H. Maurer, R. Staudt, S. Heiland, L. Duembgen, and W. Kuschinsky. 2000. Increased cerebral glucose utilization and decreased glucose transporter Glut1 during chronic hyperglycemia in rat brain. Brain Res. 858:338-347.

Estrada, D. E., E. Elliott, B. Zinman, I. Poon, Z. Liu, A. Klip, and D. Daneman. 1994. Regulation of glucose transport and expression of GLUT3 transporters in human circulating mononuclear cells: Studies in cells from insulin-dependent diabetic and nondiabetic individuals. Metabolism 43:591-598.

Fu, Y., L. Maianu, B. R. Melbert, and W. T. Garvey. 2004. Facilitative glucose transporter gene expression in human lymphocytes, monocytes, and macrophages: A role for GLUT isoforms 1, 3, and 5 in the immune response and foam cell formation. Blood Cells Mol. Dis. 32:182-190.

Fukuzumi, M., H. Shinomiya, Y. Shimizu, K. Ohishi, and S. Utsumi. 1996. Endotoxin-induced enhancement of glucose influx into murine peritoneal macrophages via GLUT1. Infect. Immun. 64:108 112.

George, D., M. Eirini, B. Eleni, P. Katherina, P. Chryssa, and A. R. Sotirios. 2005. Evaluation of glucose transport and its regulation by insulin in human monocytes using flow cytometry. Cytometry A $64 \mathrm{~A}: 27-33$.

Goff, J. P. 2006. Major advances in our understanding of nutritional influences on bovine health. J. Dairy Sci. 89:1292-1301.

Govers, R., A. C. F. Coster, and D. E. James. 2004. Insulin increases cell surface GLUT4 levels by dose dependently discharging 
GLUT4 into a cell surface recycling pathway. Mol. Cell. Biol. 24:6456-6466.

Haber, R. S., S. P. Weinstein, E. O'Boyle, and S. Morgello. 1993. Tissue distribution of the human GLUT3 glucose transporter. Endocrinology 132:2538-2543.

Hansen, P. A., L. A. Nolte, M. M. Chen, and J. O. Holloszy. 1998. Increased GLUT-4 translocation mediates enhanced insulin sensitivity of muscle glucose transport after exercise. J. Appl. Physiol. $85: 1218-1222$.

Hwang, D.-Y., and F. Ismail-Beigi. 2001. Stimulation of GLUT-1 glucose transporter expression in response to hyperosmolarity. Am. J. Physiol. Cell Physiol. 281:C1365-C1372.

Ingvartsen, K. L., R. J. Dewhurst, and N. C. Friggens. 2003. On the relationship between lactational performance and health: Is it yield or metabolic imbalance that cause production diseases in dairy cattle? A position paper. Livest. Prod. Sci. 83:277-308.

Ingvartsen, K. L., and N. C. Friggens. 2005. To what extent do variabilities in hormones, metabolites and energy intake explain variability in milk yield? Domest. Anim. Endocrinol. 29:294-304.

Kimura, K., J. P. Goff, M. E. Kehrli Jr., and J. A. Harp. 1999. Phenotype analysis of peripheral blood mononuclear cells in periparturient dairy cows. J. Dairy Sci. 82:315-319.

Livak, K. J., and T. D. Schmittgen. 2001. Analysis of relative gene expression data using real-time quantitative PCR and the 2(-Delta Delta C(T)) method. Methods 25:402-408.

Llewellyn, S., R. Fitzpatrick, D. A. Kenny, J. J. Murphy, R. J. Scaramuzzi, and D. C. Wathes. 2007. Effect of negative energy balance on the insulin-like growth factor system in pre-recruitment ovarian follicles of post partum dairy cows. Reproduction 133:627-639.

Lomax, M. A., G. D. Baird, C. B. Mallinson, and H. W. Symonds. 1979. Differences between lactating and non-lactating dairy cows in concentration and secretion rate of insulin. Biochem. J. 180:281-289.

Lucy, M. C., H. Jiang, and Y. Kobayashi. 2001. Changes in the somatotrophic axis associated with the initiation of lactation. J. Dairy Sci. 84(E-Suppl.):E113-E119.

Malide, D., T. M. Davies-Hill, M. Levine, and I. A. Simpson. 1998. Distinct localization of GLUT-1, -3 , and -5 in human monocytederived macrophages: Effects of cell activation. Am. J. Physiol 274:E516-E526.

Maratou, E., G. Dimitriadis, A. Kollias, E. Boutati, V. Lambadiari, P. Mitrou, and S. A. Raptis. 2007. Glucose transporter expression on the plasma membrane of resting and activated white blood cells. Eur. J. Clin. Invest. 37:282-290.

Mattmiller, S. A., C. M. Corl, J. C. Gandy, J. J. Loor, and L. M. Sordillo. 2011. Glucose transporter and hypoxia-associated gene expression in the mammary gland of transition dairy cattle. J. Dairy Sci. 94:2912-2922.

Mavros, Y., D. Simar, and M. A. Singh. 2009. Glucose transporter-4 expression in monocytes: A systematic review. Diabetes Res. Clin. Pract. 84:123-131.

Newsholme, P. 2001. Why is L-glutamine metabolism important to cells of the immune system in health, postinjury, surgery or infection? J. Nutr. 131:2515S-2522S.

Pantaleon, M., M. B. Harvey, W. S. Pascoe, D. E. James, and P. L. Kaye. 1997. Glucose transporter GLUT3: Ontogeny, targeting, and role in the mouse blastocyst. Proc. Natl. Acad. Sci. USA 94:3795-3800.

Park, Y. H., L. K. Fox, M. J. Hamilton, and W. C. Davis. 1992. Bovine mononuclear leukocyte subpopulations in peripheral blood and mammary gland secretions during lactation. J. Dairy Sci. 75:998-1006

Politis, I., N. Hidiroglou, J. H. White, J. A. Gilmore, S. N. Williams, H. Scherf, and M. Frigg. 1996. Effects of vitamin E on mammary and blood leukocyte function, with emphasis on chemotaxis, in periparturient dairy cows. Am. J. Vet. Res. 57:468-471.

Preisler, M. T., P. S. Weber, R. J. Tempelman, R. J. Erskine, H. Hunt, and J. L. Burton. 2000. Glucocorticoid receptor expression profiles in mononuclear leukocytes of periparturient Holstein cows. J. Dairy Sci. 83:38-47.

Reddy, A. B. M., S. K. Srivastava, and K. V. Ramana. 2010. Aldose reductase inhibition prevents lipopolysaccharide-induced glucose uptake and glucose transporter 3 expression in RAW264.7 macrophages. Int. J. Biochem. Cell Biol. 42:1039-1045.

Rodríguez-Enríquez, S., L. Carreño-Fuentes, J. C. Gallardo-Pérez, E. Saavedra, H. Quezada, A. Vega, A. Marín-Hernández, V. OlínSandoval, M. E. Torres-Márquez, and R. Moreno-Sánchez. 2010. Oxidative phosphorylation is impaired by prolonged hypoxia in breast and possibly in cervix carcinoma. Int. J. Biochem. Cell Biol. 42:1744-1751.

Roher, N., V. Samokhvalov, M. Diaz, S. MacKenzie, A. Klip, and J. V. Planas. 2008. The proinflammatory cytokine tumor necrosis factor-alpha increases the amount of glucose transporter- 4 at the surface of muscle cells independently of changes in interleukin-6. Endocrinology 149:1880-1889.

Shafer-Weaver, K. A., C. M. Corl, and L. M. Sordillo. 1999. Shifts in bovine CD4+ subpopulations increase T-helper-2 compared with T-helper-1 effector cells during the postpartum period. J. Dairy Sci. 82:1696-1706.

Smoak, I. W., and S. Branch. 2000. Glut-1 expression and its response to hypoglycemia in the embryonic mouse heart. Anat. Embryol. (Berl.) 201:327-333.

Sordillo, L. M., G. A. Contreras, and S. L. Aitken. 2009. Metabolic factors affecting the inflammatory response of periparturient dairy cows. Anim. Health Res. Rev. 10:53-63.

Sordillo, L. M., G. M. Pighetti, and M. R. Davis. 1995. Enhanced production of bovine tumor necrosis factor- $\alpha$ during the periparturient period. Vet. Immunol. Immunopathol. 49:263-270.

Sordillo, L. M., and K. L. Streicher. 2002. Mammary gland immunity and mastitis susceptibility. J. Mammary Gland Biol. Neoplasia $7: 135-146$.

Steibel, J. P., R. Poletto, P. M. Coussens, and G. J. Rosa. 2009. A powerful and flexible linear mixed model framework for the analysis of relative quantification RT-PCR data. Genomics 94:146-152.

Zhao, F.-Q., W. T. Dixon, and J. J. Kennelly. 1996. Localization and gene expression of glucose transporters in bovine mammary gland. Comp. Biochem. Physiol. B Biochem. Mol. Biol. 115:127-134.

Zhao, F. Q., D. R. Glimm, and J. J. Kennelly. 1993. Distribution of mammalian facilitative glucose transporter messenger RNA in bovine tissues. Int. J. Biochem. 25:1897-1903.

Zhao, F. Q., and A. F. Keating. 2007. Expression and regulation of glucose transporters in the bovine mammary gland. J. Dairy Sci. 90(E-Suppl.):E76-E86.

Zhu, L. H., L. E. Armentano, D. R. Bremmer, R. R. Grummer, and S. J. Bertics. 2000. Plasma concentration of urea, ammonia, glutamine around calving, and the relation of hepatic triglyceride, to plasma ammonia removal and blood acid-base balance. J. Dairy Sci. 83:734-740. 